\title{
Professional Ethics and the Education of Engineers at the International Islamic University Malaysia
}

\author{
Ibrahim M. Zein
}

\begin{abstract}
Abstact
This article focuses on professional ethics for engineers and engineering students at the International Islamic University Malaysia (IIUM). Due to the phenomenological interest in the theory of value and its realization within the framework of the professional ethics of engineers in a particular educational institution, this research applies a methodic strategy to address two levels of discourse equally. Thus, the theoretical aspect utilizes the tools of textual strategies and content analysis, whereas the specific case of the IIUM's engineering faculty serves as a source of my phenomenological reflections on professional ethics for engineers.
\end{abstract}

Despite being based on a limited source of data, some of the phenomenological remarks might be useful for other institutions of higher learning, for the stand on the theory of value used here is for both the values' universality and relationality to human beings or, more directly, both the universality and rationality of an ethical discourse. Although largely an Islamic interpretation, this article's main contributions are how to overcome this predicament in ethical sensibility, ward off dismissive gestures, and distinguish between values and their realization in the everyday world. By this process, the human agent discovers, rather than makes, values and comes to understand that ethical sensibility is not about truth and falsehood, but about the person's degree of realization.

Ibrahim M. Zein is a professor in the Department of Usual al-Din and Comparative Religion, Kulliyyah of Islamic Revealed Knowledge and Human Science, International Islamic University Malaysia. His research interests are in professional ethics and the history of religions. 


\section{Introduction}

The starting point in any ethical discourse on professional ethics is the human being and his/her relationship to the realm of values. When values are perceived as relative to the human being, then the door is wide open for all types of relativism in ethics. The Islamic stand on ethics, which emphasizes that values are relational to the human being, allows us to discover, rather than make, values. In this regard, Islamic humanism will be the ethical choice to substitute secular humanism. While the former emphasizes universalism, the latter is associated with particularism. This makes Islamic humanism perhaps the only viable voice for the universality of ethics. ${ }^{1}$

This paper argues that the foundation for a sound professional ethics must be based on universal values. As a form of applied ethics, it must be connected to a system of metaphysics other than itself because the nature of a metaphysical system is to serve as an external system of meaning. In light of this, the Islamic metaphysical system provides two sets of valuational hierarchies: (1) on that is completely connected to the belief system and worldview and (2) one that is directly connected to particular ethics. Although they are interrelated and may be seen in one hierarchical system, the distinction between them is functional rather than a matter of principle.

As professional ethics mainly focuses on practical values, one can suggest the following values that determine the nexus of values between sociopolitical or socio-cultural groups. These values, which were given to Muslims in Q. 4:58-59 at a decisive moment in the young community's history (i.e., Makkah's liberation) can govern a valuational exchange regarding the discussion of professional ethics. ${ }^{2}$ They are trust, justice, obedience, and the ethics of disagreement, the main practical values to be realized by this submission. These should be regarded as the main values in any discourse on the ethics of action and intent guided by a highly sophisticated ethics of ummatism in a comprehensive value system. ${ }^{3}$

One might be curious to know the difference between ethics in general and professional ethics in particular. Are they connected with each other in such a way that one could say that ethics, as a branch of philosophy, is connected to axiological issues and other theoretical matters, whereas professional ethics, as a branch of sociology, rather focuses on a practical set of values and their realization within a specific social domain? If so, this distinction assures us that ethicists at the philosophical level deal with ethical issues at the level of such, whereas ethicists at the sociological level deal with the same issues at the level of this. Due to this distinction, the social is connected with the em- 
pirical code of behavior and hence the relative aspect of values. This will leave the philosophizing activities (e.g., the theory of values and others) to those ethicists who are not interested in professional ethics and are more interested in the universal dimension of axiology.

Perhaps some may suggest that the difference is not between "this" and "such" levels, but that it is between those who have concluded that ethics must be tackled from an interdisciplinary approach and those who still believe that prior to any ethical discourse we must be clear about the debate's theoretical foundation. This means, among other things, that both of them must be a part of any learned discussion about ethics. Thus, professional ethics as an interdisciplinary project should not do away with the theoretical issues regarding axiology. From this perspective, at least, one has to identify right at the beginning of any discussion on ethical issues the theoretical ethical framework within which he/she operates to inform readers of his/her basic axiological assumptions and ethical sensibility. ${ }^{4}$ That might be a basic requirement in some cases, since the interdisciplinary approach leads to a development of a set of synthetic propositions.

Business ethics has assumed a considerable importance in the discussion of professional ethics ${ }^{5}$ because it encompasses the ethical courses of a number of professions. Moreover, its related issues are of primary concern to managers, engineers, bankers, and others. More to the point, business ethics is essentially interdisciplinary in nature and thus has developed rapidly and includes the ethical sensibilities of nearly all professions. Perhaps only the medical and legal professions have managed to maintain a certain distance and develop independently. ${ }^{6}$

However, there is a considerable overlap between medical and legal ethics on the one hand and business ethics on the other. This might lead some to believe that, although the latter is relatively new and has developed a quite significant amount of literature, might soon make the latter sub-categories within its own general umbrella. This line of development of professional ethics under the ever growing interdisciplinary area of business ethics might finally recast or change the orientation of other professional ethics in order to suit the general parameters of business ethics. This might be the case regarding the main issues of professional ethics, but then again minor issues may still completely retain the uniqueness of both medical and legal ethics.

It seems that engineering professional ethics will be subsumed within business ethics, for designing and building machines, vehicles, roads, bridges, and so on is always part of a major business activity. Due to this the very identity, engineering is largely part of something other than itself. Having said 
that, this does not mean that the engineers' transforming of scientific knowledge into designing or building specific things is not a well defined activity that deserves to maintain the status of a separate and distinct profession. ${ }^{7} \mathrm{On}$ the contrary, it is a recognized professional body. But when dealing with professional ethics as an area study, one finds it more convenient to subsume issues arising from such activities into business ethics. In addition, it equally important to state that those ethical issues of concern to engineers are the same as others when the focus is on moral education, work ethics, and other relevant ethical issues governing the industry. Thus, it is neither desirable nor realistic to separate engineering's ethical issues from the broader interdisciplinary approach of business ethics.

Our prime objective in this paper is to comment mainly on how to develop a set of ethical values that will help academics train engineers who both are willing to realize and discover values in their professional activities. This may require an impartial analysis of the university's required courses, which are meant to provide students with an Islamic worldview and relevant reading materials regarding Islam's basic teachings. ${ }^{8}$ In addition, a course on professional ethics has been developed for engineering students. Although the target group for these required courses is Muslim students, the course on professional ethics is designed for both Muslims and non-Muslims. ${ }^{9}$ When looking into these courses, we need to understand the relevancy of Islam to the engineering sciences. Most importantly, we need to develop a system of professional ethics that is in line with both the Islamic worldview and universal rationalism, one that is based on a position that differentiates between values and their realization in this world.

\section{Professional Ethics and the Realm of Values}

Since the main focus of professional ethics is values, one needs to understand the latter's place in professional codes of ethics, their relationship to humans, and how they have been articulated in terms of their essence and realization. To begin with, the previous comment on professional ethics shows that this type of ethical domain is a specialized discourse on practical ethics. ${ }^{10}$ This makes it a little bit innocent as regards the complexities of philosophical discussions on axiology, the theory of value, and the logical status of moral statements. In short, professional ethics is more interested in the meaning of a moral choice and how this leads to a realization of value, and, moreover, how the moral value that has been realized in a specific human action relates to a set of values guided by a metaphysical vision. 
This worldview or metaphysical vision defines who we are and gives meaning to our life. Thus, any definition that explains who we are in terms of our material needs and completely ignores the spiritual dimension of the human being is a materialistic worldview that obviously governs both the ethical sensibility and realization of values in our life. Remember that these values are the human values that can be realized within this materialistic worldview. Thus they cannot be classified as false values or disvalues. All that can be said about them in negative terms is that they are the realization of the most rudimentary aspects of values.

Moreover, in a learned ethical discourse the concern is not so much about negativity, but with how to realize more values in a given human act. This focus leads to the attitude that those who see more values in a concrete set of ethical acts are obliged to enlighten others. By doing so, those who adhere to the materialistic worldview will compare their position to that of another ethical sensibility that discovers more values in a specific human act. Although this comparison will not be done automatically, the very definition of who we are will be the bone of contention in rival worldviews. In this regard, the more the worldview can realize more values in our action, the more people from other worldviews will be attracted to it. Once again, the most fundamental issue is the fact that worldviews have the power to direct and guide the human being, and yet the person's natural disposition has an inner light that can assess a moral discovery during the process of realizing more values in specific human act.

One may ask about the relationship between worldview and the very definition of the human being. ${ }^{11}$ The answer can perhaps be given when the definition of who we are can be seen as the most fundamental question, for given its central position, mistakes that occur within its answer - the basic one being how we articulate our worldview - are always open to correction. When the worldview defines and explains less and less of who we are, a reality that takes us some time to realize, it is in open conflict with our natural disposition. But the more others who adhere to a different worldview start to discover and realize more values in a specific human act, the higher will become the chances for us to question the validity of our own worldview.

Although there is very little likelihood of this happening overnight, the process of discovering and then realizing more values in a specific human act is both educational and can create an irreversible positive change in the person, one that will certainly cause him/her to abandon a worldview that cannot see and realize more values in a specific human act. Given that this relationship between worldview and our human identity prioritizes who we are, one can 
say that the choice to adhere to a specific worldview can be rectified or informed by the ethical discoveries made by other human beings. In other words, we have the capacity to recognize the realization of more values in the acts of other humans.

We may not be able to realize more values in a specific moral choice, but we will be ethically moved by the moral choices of others that result in the discovery of more values in that specific act. The accumulation of more realized values by others who adhere to a different worldview may not automatically make us to abandon our worldview; however, it will quickly alert us to the shortcomings of our worldview because the realization of values has a great influence upon us as humans. Any worldview that does not go hand in hand with this basic tenet of who we are will gradually be sidelined, if not completely abandoned.

If the previous analysis of the relationship between our human identity and the worldview to which we adhere as a fundamental moral choice is plausible, then the realm of values is not relative to us. We have the capacity to realize moral values by our acts. Values, in this regard, are relational to our acts. In themselves they belong to the axiological or ideal level. However, their realization is subject to our moral choices in this world. This distinction between values and their realization is of an utmost importance, which means that the axiological discourse is almost invariably marked by the realization of more or less values rather than a discussion of truth and falsehood. Since values are relational to humans, we can only realize in our moral actions more or less values in a specific act. As such, the discovery of more values while realizing a specific value in a human act is both the act of the human agent and the observation of other humans of that act of realization. This act of realization, at some point, redefines who we are to ourselves and to those who observe us.

Professional ethics has two dimensions, ${ }^{12}$ one of which is general in nature and the other, which is specific and connected to a practical code of ethics. Although the former is more inclusive and a direct result of the process of general education and socialization, the specific set of a professional code of ethics is based upon a conscious articulation of those practical values that govern the exchange of valuational activities in a certain profession. Due to this deliberate act of articulation of thoughts and feelings regarding a specific profession, the code of ethics reflects the accumulated and shared experience of those who have the moral capacity to discover the essential norms of their profession. We must not think of this as existing in isolation from the general dimension, for a code of professional ethics 
can only be meaningful if it is in harmony with the general ethical framework. In fact, professional values are meant to be a more focused valuational discovery.

In this regard, a code of ethics for a specific profession is, generally speaking, a good approximation of the degree to which it has realized that set of values relevant to itself and will certainly enrich our understanding of these values. More to the point, we, as moral agents, will be able to see a higher degree of realization of these values and refocus the whole edifice of values related to our profession. In short, one can expect that such a realization within the framework of a specific profession will both enlighten us about these values and entice others to follow suit.

This process of value discovery and moral education is rather complex, for it evidently reflects the interaction between the general dimensions of professional ethics and the specific code of ethics in that profession. ${ }^{13}$ In this respect, engineers know that being wasteful is a disvalue. Due to their capacity to produce more serious waste (e.g., nuclear waste) than others, their decision to not commit this degree of appalling disvalue must be highly regarded. Armed with this knowledge, engineers must be more careful and sensitive than others. ${ }^{14}$ Therefore, there is a sense of proportionality between the realization of values and the capacity of human beings to act. As a result, professional ethics is, among other things, about that sense of proportionality and accountability. This is equally true whether an action realizes a disvalue or a value.

A would-be engineer is, essentially, a moral agent who pursues his/her education with that capacity. ${ }^{15}$ The moral discovery that can be achieved through a certain level of education in terms of professional ethics will enhance the this person's moral sensibility of that set of ethical values that are, by now, invariable. The only difference is the degree of their realization. By going through a code of professional ethics, all engineering students will be expected to realize these values more than others. However, a moral agent always has the freedom of choice either to commit oneself to realize more values or not. Even worse, they can choose to disturb the hierarchy of values and create a great deal of trouble in the vistas of values. Therefore, ethical education for engineers is largely meant to refocus their moral campus and help them make a meaningful moral choice. ${ }^{16}$ Most important of all, they must discover the humanness in themselves at all times. This certainly includes the negative moment of disturbing the vistas of morality. After all, no human being has ever been free of mistakes or failed to realize more values in his/her acts. ${ }^{17}$ 


\section{The Hierarchy of Values and the Metaphysical System}

Since this discussion on professional ethics is largely about developing an Islamic perspective to discover universal values, the basic definition of who we are is a proper starting point. Obviously, the correct place to start is the Qur'anic account of creation, which was given as both a commentary and an interpretation of the Biblical account. In view of this important connection, the Judeo-Christian tradition will be engaged in this discussion. ${ }^{18}$ Some may view this as a digression from the subject of professional ethics; however, one can reply that the particular religious or metaphysical imagination to which we subscribe makes us who we are and how we understand the fundamental questions.

A look at the basic terms present in the Qur'anic account enables us to see their relevancy to our understanding of the valuational discourse on professional ethics. The most visible term is khaliffah (vicegerency), ${ }^{19}$ a status that God bestowed upon this new creature before its creation. According to the Qur'an, God designated this specific title for this creature as its ultimate becoming. Although this gender-less creature is supposed to dwell on Earth in order to fulfill its particular status, it was granted a transitional period, perhaps for training, during which they came to know who is their archetypal enemy, where to seek guidance, the meaning of moral responsibility, and, above all, who their Creator is and what are their duties toward Him.

Having established these basic issues that render a meaningful and consistent ethical position on who we are, the Qur'anic account then develops a moral vision that constitutes the base of its view of professional ethics. This means that for a sensible valuational discourse, we need to possess a set of suppositional answers for the fundamental questions about who we are and the meaning of life. Without such answers, there is a very large possibility right at the beginning of the discussion that we will encounter a circular argument, a deliberate moral relativism, or a cynical view of morality. To avoid such unpleasant and perhaps unacceptable situations, one needs to be constructive by openly declares his/her position on these questions and hence develop a consistent moral stance in accordance with these answers.

By doing so, the valuational discourse can be considered a constructive discussion that leads to a set of universal values. Obviously, there will be a way to detect mistakes within the system due to internal inconsistencies and to differentiate between these types of errors and the absurdity that has been created by both flawed arguments and erroneous assumptions about who we are. Having such a position will allow us to accelerate both the process of dis- 
covering and realizing values in a human act. Remember that the religious or metaphysical imagination to which we adhere is invariably a rich source for discovering who we are and, consequently, the set of hierarchical values that we should follow while realizing our moral mission.

In this regard, the Qur'anic story of creation given in Sürat al-Baqarah and Sürat al-A'rấf ${ }^{20}$ declares a set of principles concerning our being as unique creatures that possess both the cognitive and moral capacities necessary for assuming the role of khiläfah on Earth. The major difference between our archetypal enemy Satan and us is that he did not obey God's command and, even worse, challenged the very act of commandment. Moreover, he sank to the depths of despair and blamed humanity for his moral failure. But Adam and Eve, when they failed to obey God, took full responsibility for their act and beseeched God to forgive them. ${ }^{21}$ As a result, they were considered ready for their moral mission. In the Qur'anic narrative, they are reminded time and again of their enemy as well as of their cognitive and moral capacities. ${ }^{22}$

Humanity, both male (Adam) and female (Eve), agreed to be endowed with this particular quality of moral valuation and accept the subsequent moral responsibility that marked the essence of their definition. By accepting this amānah (trust), they assumed the status of being the only bridge between the realm of values and the concrete world. ${ }^{23}$ Thus, values can be actualized only by the actions of human beings, for only their moral choices can bring them to realization in this world. This unique position also entails each person's moral acts being governed by intentionality. Whatever has been done within the ethics of intent's framework will pave a way for a value to be realized in this world. Likewise, any act based upon utility or consequence will never be part of the process of realizing values. In other words, not all human acts are the concern of morality. In fact, only those acts governed by intentionality as a moral choice can be classified as part of the moral domain, for only those acts activate humanity's role as a bridge between the metaphysical realm of axiology and the empirical world.

It should be remembered that humanity's moral vocation is an existential duty, for being human means that one is responsible for carrying out the duties of a trustee for he/she is essentially a moral agent who is able to engage in moral reasoning. One can say that an essential part of being human is the possession of this strong sense of moral vocation, for values can neither enter the physical world through non-humans and be realized in their acts. It is equally true that the same human being can allow a disvalue to disturb the whole vista of morality. Given these facts, the human being is the vantage point of both value and disvalue. 
In the Qur'anic account of creation, it seems the khaliffah has a cosmic value. ${ }^{24}$ Adam, the historic male creature and equally his female counterpart Eve, are supposed to realize that cosmic value while dwelling upon Earth. Although they were given a training period and a direct audience with God, unlike their descendants, they were the first to realize their cosmic value on Earth. At that time it was nearly impossible to distinguish between the historical and the cosmic realization of the khaliffah. They were the historical khalifah, and yet it was known that the ability to realize the cosmic value of this status is an open-ended one. The most significant difference between any human being at any point of time and them is that the former is capable of reliving the history of the cosmic value with all of its positive and negative realizations. The human drama since the time of Adam and Eve is nothing but the khalifah's continuous accumulation of both values and disvalues. Thus humanity watched its own story unfold before its very eyes. This human ability to be both an active participant in the realization of the cosmic status of khaliffah and observing the realization of its values and disvalues is the hallmark of who we are.

When God informed the angels of His plan to create a khaliffah on Earth, their first comment was that humanity would shed blood and fill Earth with trouble and corruption. And yet, in God's wisdom that cosmic status had a cosmic value that transcended such things, ${ }^{25}$ for its realization will enable values to enter this world via humanity, the sole bridge between the realm of axiology and the empirical world. Although after humanity's beginning God becomes the ultimate ghayb (the unseen world), His attributes are the values that ought to be realized on Earth. As such, our cognitive capacity will allow us to acquire the knowledge of who we are, of the external world, and of God's attributes. In addition to this knowledge-based ability, we are endowed with a valuational capacity.

This conception of who we are, as presented in the account of creation, has a direct implication for our understanding of professional ethics. Let's start the discussion with the valuational datum that values are refreshingly energizing and both known to us, and that they seek to be realized in human acts. According to the Qur'an, our creation tells us that love for the Creator translates into a sense of obedience that results in a sincere willingness to submit our will to His. In all sincerity, all people attempt to identify themselves with the Creator's attributes; when they fail in this attempt, they seek forgiveness and genuinely learn from their mistakes. Given these realities, it seems that teaching values is possible and that they resonate with human emotions and sensibilities. This allows us to train the human sense of value 
in such a way that people become able to discover values and to know their valuational structure.

By such moral training, human agents will be able to discern a number of different dimensions of valuational education. First, they will no longer have to depend solely upon their moral intuition in matters concerning valuational structure and discovering the place of specific values in a valuational hierarchy. Second, they will be able to develop moral insights in the systematization of values regarding their specific profession within the general moral sensibility. Third, provided that this has been done systematically, they will gradually come to possess a rational and objective way of speaking about values. More to the point, we can comfortably afford to speak about universal values within this community of learners who show great discernment in their moral reasoning.

Once again, the importance of the creation story lies in its ability to provide us with an authoritative answer for the basic question of who we are. In addition to that, the general narrative has alluded to the cosmic value of khalifah and the historical realization of the main values. Although this was done in a highly complex set of narratives, the main characteristics of a valuational structure can easily be outlined for a proposed professional ethics for engineers. Obviously, the creation story and its moral structure is an important aspect of humanity's accumulated wisdom for those who do not believe in its divine origin. In this regard, its moral reasoning should be the focus of analysis, and the real test of its meaningfulness will certainly reside in the fact whether it resonates with the human disposition or not. It is true that this account is a shared legacy of human wisdom, despite its different forms of narrations in various religious traditions. ${ }^{26}$ In addition, the ethicist is obliged to fathom the depths of this influential account in the history of humanity. And given that it provides Muslims with revelational data that need to be understood, it is equally true that for nonMuslims it is part of the human wisdom that needs to be included if we are to formulate a meaningful account of who we are.

With this strategy of intellectual engagement based on the story of creation, the biographies of prophets, sages, and influential human beings will constitute the basic requirement for the comprehensive data needed to discover the professional ethics for a specific profession. Since our prime concern in this regard is engineers, the historical narrative requires an understanding of the biographies of those who are relevant to the profession throughout its development within the grand context of human history. This might seem to be a daunting task, but this is an important step in our attempt to refocus the existing projects of professional ethics to acquire a monumental and systematic understanding of professional ethics. 
This shows, equally, that what currently exists is no more than the accumulation of an historical development of the realization of values through these people's acts. Now it is the time to make sense of this human achievement in professional ethics by understanding the process of realizing these values within a professional community. One's understanding of the valuational structure of these biographies or revelational data will not be drastically affected by one religious affiliation. Certainly, a phenomenological approach is the most appropriate method for both understanding the historical records and the interpretative valuational strategies necessary for making a grand narrative.

The education of Muslim engineers requires a thorough analysis of both the revelational data and historical records of biographies of the abovementioned people; however, more is needed to develop a hierarchical set of professional values. Obviously, Muslims have abundant historical materials. However, the essential endeavor is to systematize this material in a grand universal narrative by consciously applying the phenomenological method, which will engender great achievements regarding both the grand narrative and the hierarchical set of professional values. Historically, Muslim civilization was marked by its ability to appropriate earlier civilizations' advancements in science and technology as well as its ethical zeal to recognize valuational structures in accordance with its axiological principles. ${ }^{27}$

In this regard, a detailed investigation into the biographies of Muslim engineers such as al-Biruni and others will lead to a wealth of information concerning professional ethics in its historical formation. ${ }^{28}$ Naturally, these biographies are connected with that of the Prophet, just as the latter's biography is closely connected with the biographical data of the messengers sent by God before him. This is a recurrent theme in the biographical dictionaries written by Muslims. More to the point, these sources also include non-Muslims. Due to this inclusive aspect of Islamic civilization, one would be rather safe in saying that its universalism is a true representation of a humanistic valuational structure. Mindful of this legacy, the professional values resulting from this investigation will be both rational and universal in nature. Therefore, applying the phenomenological method will definitely render an accurate understanding of the life-values contained within this material.

Indeed, the thoroughness of the inquiry is the only guarantee that the genuine hierarchical values representing the humanistic valuational structure of Islamic civilization will be discovered. Of course the issue of this material's authenticity must be taken into account. But it should be noted that this ma- 
terial at least reflects the mindset of the era in which it was produced. The awareness of these shortcomings is important, as it enables us to avoid making any sweeping generalizations or going beyond the available evidence.

To sum up, there are two main necessary postulates: One concerns the metaphysical system or the religious imagination, and the other is the historical record of realizing the values that emanate from the metaphysical system. Both of these are essential to systematizing a set of principles to regulate a hierarchy of professional ethics, as well as in terms of the steps taken to rectify any erroneous systematization of values. In this regard, the grand narrative of value realization either from the Qur' anic data about the creation story and the biographies of the prophets, or their historical realization in the biographies of leading engineers in Islamic civilization, will constitute the resource material for both a code of ethics for engineers and a guiding manual for professional ethics for engineers. The final outcome of this phenomenological approach will be a universal and rational valuational structure that, although based on Islamic sources, it is equally humanistic in nature. Therefore, it will be relevant to Muslims and non-Muslims alike. Muslims will be able to acknowledge the spiritual dimension of this valuational exercise, whereas non-Muslims will certainly feel committed to realizing its humanistic and rational aspects.

\section{The Hierarchy of Values in Applied Ethics}

In recent years, the discourse on engineering's applied ethics has been dominated by issues regarding safety, risk, and professional responsibility ${ }^{29}$; technical issues like who should teach engineering professional ethics; and whether it is advisable to have separate courses on professional ethics or not. ${ }^{30}$ Other questions have been whether ethical values should be integrated into the engineering curriculum and whether the role model for professional ethics should be taken from people other than engineers. ${ }^{31}$ Although these concerns are important, one has to keep in mind that before any of these questions are settled, there must be a set of core of values that governs the valuational discussion, a set that represents the main life-values that direct the general moral vision of both the individual and the professional community. Although the former is the most essential part of this valuational structure due to his/her freedom of choice, that individual has to be seen as part of a professional community that is connected to a society that is part of humanity at large. This interconnectedness needs to be emphasized so that we can acquire a better understanding of who we are and the systematization of values. 
In this regard, the hierarchy of values will cut across the levels of the individual, the professional community, society, and humanity at large. This means that the systematization of core values is, in fact, the systematization of life-values. Their representation on each level is a matter of the degree to which these values have been realized within specific contexts, which indicates that these same core values will be those that guide the moral vision at each level. More to the point, their systematization will equally be the same because the only substantial difference will be the degree of their realization within the moral dynamics of the specific context.

Remember that each level has its own specific moral dynamics and thus the power to affect the degree of realization of values, but not the hierarchy of those values. This implies that the human agent can discover more values within that specific context, provided that he/she is morally sensible and professionally competent. Obviously, moral sensibility can be taught and professionalism can be acquired through systematic training. Therefore, the university-level curriculum designed to educate engineers must focus on these two interrelated areas so that the would-be engineers can discover and realize more values in their daily activities as professionals. ${ }^{32}$

One important fact about the values given in Sürat al-Nis $\bar{a}^{\prime}$ is that this was the first and perhaps the last time that the Qur'an directly commanded Muslims to realize these values in a specific order. Most important of all, the Qur'an places these values in different settings and yet here it connected them with each other in a whole set governing the community's sociopolitical relationship at a time when the Muslims achieved their decisive victory: the liberation of Makkah from the polytheists. Obviously, this showed the people that the adherents of Islam's message was ready to lead humanity according to the divine plan. ${ }^{33}$ Given this reality, a final set of core values that should govern humanity's sociopolitical affairs was revealed so that its members could fulfill their divine mission.

Evidently trust, justice, obedience, and the ethics of disagreement are well-known values. What is new in this regard, and certainly can be considered as a great moral discovery, is that they are now a complete set of values that is capable of creating new moral vistas. Some might call this a set of core values. No doubt this is a set of essential values that can govern and regulate the valuational discussion. Again, we must realize the importance of the ethical procedures in the ethics of disagreement. This means that although these four values are considered to constitute the valuational structure, the ethics of disagreement remains the source that binds the other three values in a hierarchical valuational structure. 
In this regard, trust will pave the way for a genuine realization of justice, which is the foundation of obedience. Within this moral vista, disagreement must be governed by a set of ethical procedures deeply embedded in the overall valuational structure outlined above. The hierarchical structure is the most important principle for a meaningful realization of these values; however, the regulatory principle governing any disagreements is both constitutive and more fundamental. Therefore, educating would-be engineers will focus on two main objectives: (1) systematizing these values within the given valuational structure (i.e., the existing code of engineering professional ethics must be cast in the mold of the valuational structure of trust, justice, obedience, and the ethics of disagreement) and (2) the university's required courses (i.e., "Islamic Worldview," "Ethics and Figh for Everyday Life," and "Islamic Science and Civilization") must reflect this new understanding of values.

In sum, the existing Professional Engineering Code of Ethics will have to be reformed and the three required courses reviewed. ${ }^{34}$ Although reforming this particular code is beyond IIUM's jurisdiction, these new moral vistas should be considered when trying to achieve a better systematization of values. Evidently, reviewing these three courses along with this new valuational structure is a necessary step toward designing a meaningful and systematic valuational education as well as for formulating well-defined parameters for educating morally sensible and professionally qualified engineers.

\section{Conclusion}

Perhaps the most important conclusion to be drawn from this study is that Islamic humanism must be located at the core of any genuine program to Islamize knowledge because developing a moral valuational structure that is meaningful only for Muslims will alienate non-Muslims. More to the point, moral relativism will appear all over the discussion and dominate the moral scene, both of which will negatively impact human interconnectedness. Thus, Islamic humanism should be based upon the universality of ethics and a critical set of rational principles ${ }^{35}$ so that this intellectual project will be both rational and universal. This is the most essential position for any ethicist who cares about other human beings to adopt.

In addition to this general epistemological stand of Islamic humanism, one can formulate a specific logical conclusion regarding the reform of Engineering Professional Code of Ethics and the extensive revision of the three required university courses. Although such a reform is beyond IIUM's jurisdiction, the university's general code of ethics can be refocused in order to develop a new 
Engineering Professional Code of Ethics. Undoubtedly, revising the three courses is meant to connect the ethical sensibility of the Islamic worldview and its manifestations in figh, science, and civilization with the specific valuational structure of a course on professional ethics for engineers. Finally, the answer to the fundamental question of who we are; the exposition of the meaning of $k$ haliffah as a cosmic value; and the valuational structure of trust, justice, obedience, and the ethics of disagreement must all be governed by Islamic humanism. Perhaps this is the only way to ward off relativism in ethics and to pave the way for the universality of ethics and human interconnectedness.

\section{Endnotes}

1. Isma'il Ragi Abul-Huda el-Faruqi, "On Justifying The Good," (doctoral thesis, Indiana University, 1952), 287-97.

2. Ibn Taymiyyah, Al-Siyāsah al-Shar' 'ìyah (Beirut, Dal al-Jiya: 1988), 3-5.

3. Isma' il Raji al-Faruqi, Al-Tawhìd: Its Implications for Thought and Life (Herndon, VA: IIIT, 1986), 61-84.

4. Isma'il Raji al-Faruqi, Christian Ethics (Montreal: McGill University Press, 1967), 1-8.

5. See John Mahoney, "Christian Perspective On Business Ethics," in Studies in Christian Ethics, Professional Ethics 2, no.1, ed. Revd Richard Franklin, T\&T Clark Edinburgh: 1989, 20-40. Henry B. Clark's response to this chapter was contained in the same book, as was Frank McHugh's comprehensive bibliography on business ethics (pp. 82-98).

6. Donald Nicolson and Julian Webb, Professional Legal Ethics (Oxford: Oxford University Press, 1999); Alfred Heijder and Herman Van Gewns, Professional Codes of Ethics (London: An Amnesty International Publication, 1976).

7. See Robert H. Haynes "Ecce ecopoiesis: Playing God on Mars," in Moral Expertise Studies in Practical and Professional Ethics, ed. Don Macniven (London and New York: Routledge, 1990), 161-83; Christopher P. McKay "Does Mars Have Rights? An Approach to Environmental Ethics of Planetary Engineering," ibid., 184-97; Abdi Omar Shuriye, Ahmad Faris Ismail, and Azweeda Dahlan, eds., Ethics of Engineering Education (Kuala Lumpur: IIUM Press, 2009).

8. Perhaps the Department of General Studies, now that it has been renamed, is the most active department in terms of writing textbooks - it produced more than six of them for the three main university-required courses.

9. It should be noted that the Kulliyyah of Engineering held several workshops and two international seminars on the ethics of engineering education. See Shuriye, Ismail, and Dahlan, eds., Ethics of Engineering Education.

10. Emile Durkheim's Professional Ethics and Civic Morals, trans. Cornelia Brookfield (London: Routledge, 1957), opened up new vistas of theorization in practical ethics. 
11. See al-Faruqi, Al-Tawhīd, 1-16.

12. With the help of the former IIUM rector M. K. Hassan, during the rectorship of Syed Arabi Idid the IIUM developed and published an official document, the "IIUM Code of Ethics." Its values and ethical sensibility has been incorporated into the staff's contracts.

13. The IIUM has also developed and published a policy paper on Islamization and the integration of knowledge.

14. A leading professor of engineering in the Kulliyyah of Engineering made this observation when I presented professional ethics in a forum there during 2012.

15. See Shuriye, Ismail, and Dahlan, eds., Ethics of Engineering Education, esp. chapters 3, 6, and 8 .

16. See Abdul Raufu Ambali, "Factors Influencing Perception and Practice of Professional Engineers" in ibid., 24-25.

17. The model of Prophet Muhammad as depicted in the Qur'an and Sunnah will testify to this. Although his moral achievement has no parallel in human history, the Qur'an and all Muslims see him as a human being. See el-Faruqi, On Justifying the Good, 290. In the footnote, he made an interesting remark concerning the three final values in the hierarchical structure of values: "History knows of only one man who combined all three in a more or less superlative degree..."

18. The Qur'an mentions the story of creation in different places. Q. 7: 10-25 and Q. 2:30-38 both give a more detailed narration of humanity's creation.

19. Muhammad Asad provides a good translation of the concept of khalifah in his Message of the Qur'an (Kuala Lumpur: Islamic Book Trust, 2011), 10.

20. Although Q. 7 is a Makkan sürah and Q. 2 is a Madinan sürah, they are complementary in terms of providing the basic principles that govern who we are.

21. This is the most significant difference between the Qur'anic and the Biblical account of creation.

22. Muhammad Fu'ad Abdul Baqi, Al-Mu 'jam al-Mufahras li Alfāz al-Qur'ān (Cairo: Dar al-Kutub al-Misriyyah, 1364 AH). For entries like amna and other words with the same root, see pp. 81-93; for al-insān, see p. 94; for al-Shaytān and other words with the same root, see pp. 382-83; for kafara and other words with the same root, see pp. 605-13; for $a l-n \bar{a} s$, see pp. 726-29; and for huda and other words with the same root, see pp. 732-36. All of these entries reflect that meaning.

23. In this verse, amānah expresses the most fundamental and unconditional value that makes the whole valuational process a meaningful discourse.

24. See Abdulaziz Sachedina "Human Vicegerency: A Blessing or a Curse? The Challenge to Be God's Caliph in the Qur'an," in Humanity before God, ed. William Schweiker, Michael A. Johnson, and Kevin Jung (Minneapolis: Fortress Press, 2006), 31-54.

25. See Asad, Message of the Qur'an, 10.

26. Humanity before God is devoted to the story of creation and the place of humanity in the three Abrahamic traditions. For an Islamic perspective with a com- 
parativist bent, see Seyyed Hossein Nasr, "Standing before God: Human Responsibilities and Human Rights," 299-320.

27. See this important biographical dictionary, which includes both Muslims and non-Muslims who contributed to science, philosophy, and technology in Islamic civilization. Zahir al-Din al-Bayhaqi, Tārīkh Hukamā' al-Islām (Damascus: Matbu'at al-Majma' al-'Ilm al-'Arabi bi Dimashq, 1946).

28. Ibid. See the biographies of al-Badi' al-Istralabī (376-80) and al-Biruni (459). In addition, see the biographical dictionary by Ibn Abi Usybiah, 'Uyūn al-Anbā', fì Tabaqāt al-Ațibā' (Beirut: Manshurat Dar Maktabat al-Hayat, n.d.) for the biographies of al-Karmani (484-85), Ibn al-Haytham (550-60), and Abu al-Fadl ibn Abdul Karim al-Muhandis (669-71).

29. See Rosli Asmawi, "Engineers' Responsibility: Safety, Risk, Liability and Negligence for Design," in Ethics of Engineering Education, ed. Shuriye, Ismail, and Dahlan, 7-13.

30. See Meftah Hrairi and Othman Khalifa, "An Integration Approach of Ethics and Professional Issues into Engineering Curriculum," in ibid., 275-81.

31. See Himawan Tri Bayu, "Teaching Engineering Ethics Using A Process Model; Leonardo da Vinci's Life Qualities and Works," in ibid., 221-30.

32. The other three UNGS courses taught at IIUM must reflect the same set of values in terms of the "Islamic Worldview," "Ethics and Fiqh for Every Day Life," and "Islam, Science, and Civilization," because these required courses are meant to provide students with the core values of the university's vision.

33. Ibn Taymiyyah, in his Al-Siyāsah al-Shar 'ìyah fì Ișlāh al-Rā '̄̄ wa al-Ra 'ìyah (Beirut: Dar al-Afaq al-Jadidah, 1988), noted the importance of Sürat al-Nisā and thus based his book on an ethical exegetical analysis of these two Qur'anic verses.

34. During the academic year 2014-15, the Department of General Studies undertook a Key Result Area Project to revise the university's required courses. This was done to conceptualize, systematize, and evaluate these courses in accordance with the university's vision and the experience gained while teaching these courses for the last fifteen years.

35. Ibrahim Mohamed Zein "Al-Faruqi's Theory of Value: A Plea for Islamic Humanism," in Islam and Knowledge: The Concept of Religion in Islamic Thought, ed. Imtiyaz Yusuf (London: I.B. Tauris, 2012). 